DOI: 10.5824/1309-1581.2017.1.002.x

http://www.ajit-e.org/?menu=pages\&p=details_of_article\&id=242

Received : 17.01.2017

Editorial Process Begin: 25.01.2017

Published: 0802.2017

\title{
Can Vloggers Characteristics Change Online-Shopping Intentions? The Role of Word of Mouth Effect as A Communication Tool
}

D. Zeynep BAYAZIT, Istanbul Commerce University, Istanbul-Turkey, zbayazit@ticaret.edu.tr

Beril DURMUŞ, Marmara University, Istanbul-Turkey, beril@marmara.edu.tr

Figen YILDIRIM, Istanbul Commerce University, Istanbul-Turkey, figen@ticaret.edu.tr

AbSTRACT Purpose - Vlogging enables individuals to share experiences, knowledge and diaries with the online community. Recently many studies have shown that vloggers' main characteristics and blog types have a direct influence on users as an effective medium. As vlogs have become an important tool for interactive communication, the purpose of this paper is to understand the relationship between vloggers'characteristics, trust, word of mouth and intention of online shopping. This study implies that the vblog can be a meaningful learning platform and the vlogging can be a significant medium in having/sharing the informal knowledge for online shopping.

Design/Methodology/Approach-Based on various theories, the structural equation modelling approach was proposed in this study. A survey with convenience sampling involving 357 vlog users as participants was analyzed in the empirical study to investigate whether the usefulness of vbloggers' recommendations and trusting beliefs towards vblogger has influence on consumers' behavioral intentions towards word of mouth and online shopping.

Findings-The results showed that vloggers' characteristics had significant influential effect on vlog users' attitude towards and intention to shop online. Moreover, the findings indicated that engagement characteristics of vloggers elicited trust more than authoritative knowledged characteristics of vloggers. As a result of the path analysis it is discovered that the intention to shop online is triggered through trust and word of mouth communication. Engagement knowledge has more power on the relationship between word of mouth communication and the intention to purchase. As much as users trust that the content of the vlog is based on true information and not for advertising strategy, the more likely they want to share the information virally. That would have a direct impact to the increasing intention to buy.

Originality/Value- The originality of this paper is to study vlogging, which is a new working field in the scholarly literature, and its correlation to users' intention to buy. This study especially analyzes the vlog characteristics and their increasingly leading factors to users/readers' attractiveness intention to buy. The value of this study concentrated on the trust issue and its positive relation to amateur vloggers instead of authorative knowledged based ones.

Keywords: Vlogging, authoritative knowledge, engagement knowledge, trust, intention of online shopping, word of mouth communication, 


\section{Introduction}

Digital technologies are rapidly growing and developing especially in terms of sophistication and number of users. Due to high interconnectivity, Internet has become an important tool in most of the sectors in the economy. The digital technologies and Internet have not only provided the means for trading but they have also created a platform where kindred spirit people can socialize, form communities and be entertained.

Social networking has changed the view on traditional -one way marketing-. This dynamic change has become an additional marketing communication channel for promotional mix. The patterns of opinion sharing, interactive communication and decision making on each level have changed through the widespread avalibility of this new communication tool. A bundle of blogs, forums and applications over the Internet present customers to be in touchgetting and sharing information- with people around them and worldwide.

Most of the digital influencers are active on blogs where blogging becomes the primary publishing tool for creating communities. The growing popularity of blogging and vlogging (or video blogging ) communities has evolved from exchanging opinions and associate on new ideas real time. These blogging communities are now used and accepted for multiple purposes especially by new generations (Morton, 2002).

Today, social networks are well established that when targeting specific audience, it is important to understand the differences in popularity of those networks. Bloggers' primary methods to influence are; writing text-editorials $(83 \%)$, microblogging like twitter (38\%), sharing photos $(36 \%)$, generating video content $(10 \%)$ and using audio technology $(4 \%)$ Facebook and Twitter are the most popular social platforms for bloggers especially in terms of generating revenues. Most blogers retained income was generated from banner advertising, texts adds, affiliated programs and brand sponsored content, respectively. Controversially, consumers tend to value YouTube, Facebook and Google+ as more popular for digital integrations (Technorati,2012). While comparing the social networks, it is best to observe active usage rather than the number of user accounts. Like most other generations, the new generation which were either born or growing up in the 'age of digitalization' would also like to be a part of this virtual socialization. They may not have a practical knowledge or real life experiences, but what they have is the excellent usage of technological

resources to reach broader audiences. Social networks are extremely important especially for generation Y, who were born between mid 1970 to 1990, to receive information, be updated with news, get entertained and give an immediate reaction. Despite the milennials reliance on independence, they desire a great need for peer acceptance and a personal need to fit in and be interacted through social networking applications (Heaney, 2007). Although, it is assumed that most blog readers are young and lower educated, unfavorably many surveys have found that most readers are also at an older age and have professional backgrounds. 
The determinant factor of blog interaction is not the users' age specifically but the well established and vital content of the site. But still it has been clarified that the age between 1835 years of users are constructing the popularity of the social media usage (Stelzner, 2011).

Blogs existed as bodies of text on a personal website or on a provider site. The content of a blog is mostly opinion and knowledge, based on personal experiences, attitudes, beliefs and backgrounds which is delivered through a combination of pictures, video, and text (Johnson \& Kaye, 2009). Vlog is a personal diary/journal on the web. Any information that is uploaded on to a website and become available to general consumption for web users is called vlogging (Scott, 2007).

The primary drivers for vlogging behaviour can be stated as entertainment, information seeking, searching for efficient utility and social interaction. Similarly, Mooney and Rollins (2008) states that vloggers are active creaters, owners and managers of content consumption by producing, sharing, influencing information.

\section{Theoretical Backround}

To reduce risk and uncertainty in buying process, consumers usually seek opinions or recommendations from others to evaluate alternatives. The risk perception is more likely feel in online buying because it is not easy to adopt and understand the digital environment.

According to the related literature, Theory of Reasoned Action(TRA) (Fishbein \&Ajzen,1975) is accepted almost first theory that aims to explain the relationship between pre-existing attitudes (an individual's positive and negative feelings about a particular behavior) and behavioral intentions including factors of age, gender, prior experience, ability, etc.

Afterwards, the Technology Acceptance Model (TAM) -is developed from TRA- predicts how users accept and use a technology (Davis,1989). Due to TAM, people's perceptions about blogging technology usage may be developed while they participate. To explain a user behavior, perceived usefulness and perceived ease of use are important factors. Perceived usefulness (PU) is defined as "the degree to which a person believes that using a particular system would enhance his or her job performance" whereas perceived ease of use (PE) is called "the degree to which a person believes that using a particular system would be free from effort"(Davis,1989).

One of the extended model, TAM3 has also been proposed in the context of e-commerce with an inclusion of the effects of trust and perceived risk on system use (Venkatesh \& Bala, 2008). In order to obtain trust and get rid of online buying risks, seeking information from blogging/vlogging become popular. Moreover, bloggers' recommendations are more reliable and valuable than information taken from commercial medium $(\mathrm{Wu}, 2011)$.

Since blogging/vlogging is a voluntary act that aims to achieve social interaction, usefulness, ease of use, and enjoyment are assumed as the factors that reflected the user's beliefs in blog usage (Hsu \& Lin, 2008). Besides, Lim et al. (2006) verified that endorsements from satisfied consumers significantly affect other consumers' purchases. 
Additionally, Lu and Lin (2003) proposed that customers' beliefs about a particular web site's content, context, and infrastructure had an impact on their buying intentions. Hsu et al. (2015) examined the factors affecting repeat purchase intention in online group buying and their study revaled that trust and satisfaction are the two key factors affecting customer's purchase intention.

To be realistic, customers should keep in their mind that vlogging/blogging is also used by companies as an influencial communication tool. Eventhough they knew that the message is mostly comes from companies, they continue to watch vlogs and share the information that is taken from vloggers. The main crucial hint for the companies is to analyze consumers' perceptions about different characteristics of knowledge. As much as they feel that information comes from experience rather than marketing strategy, vlog users more likely buy and share information.

\section{Vloggers Characteristics}

The Consumer Generated Media (CGM) - Vlog, social network insides, consumer review forms- has unique characteristics that differentiate itself from other online/offline communication tools (Fernando, 2007). The integration of CGM into marketing communication strategies is an innovative approach recently.

Firstly, vlog provides information on subjectively selected topics. Others share information on individual daily life whereas some offer personal opinions and commentaries in content. Usually vlogs can be tailored upon end-users' perspectives rather than marketers' strategies. (Lu and Hsiao, 2007).

Vloggers allow anyone to influence and reach to a provided content. Specifically vloggers are not necessarily topic area authorizers but readers may associate them with the knowledge bias. Controversial issue concerning about CGM discuss whether if the content of any blog is credible enough to form trust. That is the reason why it is necessary to study the roles of vloggers' characteristics in the process of content management.

Digital engagement and participation have matured over time that participants' creation of content and loud voice obviously becomes a crucial factor. One of the major concerns of digital engagement is the vloggers expertise to dominate the decision making in the public area. Vloggers -as the experts- tend to view end-users as clients instead of valuable resources for spreading the information. In order for leading effective social interaction, an authoritative or experience based knowledged vloggers should generate sustainable content in order to increase trustworthiness and for reinforced communication.

-Authoritative knowledge is a human capital source which a blogger could lead to the knowledge of the topic-area accurately (Chen \& Hirschhim, 2004; Ponterotte, 2005). Authoritatives generate and deal with fact based contents and are carefully backing them up with observable precedent. 
The atmosphere created by authoritative blogs provides space for people to express personal opinions and the comments function in the social construction of knowledge. These types of learning blogs are used to give information, educate and increase awareness for a selective topic. From viewers' perspective authoritative blogs operate as a cognitive learning tool rather than as a personal publishing space (Yueh et al, 2013:239-240).

-Engagement knowledge, different than authoritative knowledge, aggregates social action of participation in topic-area within the online community (Doyle et al, 2012: 840).

Engagement Knowledge occurs through involvement within the scope. It is obtained through lived experiences of the knower. The source of engagement knowledge is more experienced based rather authoritative knowledge is fact based generated contents.

\section{Trust}

Online trust is developed from an individual's belief that an online exchange partner is dependable and able to fulfill promised roles or obligations (Cho, 2006). Then, a blog trust can be defined as blog readers' expectations of bloggers positive and credible intention for sharing information. Trust and security are important concepts for consumers' perceived risk in online shopping. Trustworthiness of internet vendor and relevant external factors has an impact on effective online transactions. Ensuring the trust in general by using vloggers' effectiveness would conduct users' intention to buy with reduced risks.

As TAM, is extended by some researchers to confirm that trust has a significant impact on perceived usefulness and online shopping intention (Gefen et al., 2003; Tung et al., 2008; Egea and Gonza'lez, 2011; Hsu et al,2013).

The consumer experience can be obtained by direct ways such as searching for information, purchasing and consumption of products, or indirectly, such as exposure to propaganda and observation of other consumers. (Alba \& Hutchinson, 1987). The quality of previous experiences in digital environment plays an important role on repetation expected behaviour (Chiou, 2004).

The consumer experience is not limited to a specific product category, but it is also related to various purchasing alternatives, as well as the assessment of purchasing situations (Suk \& Mitchell, 2004). Therefore, repetitive expected behaviour as trust operationalisation; cumulative consumer experience involves two dimensions: specific experiences with the site and experiences with the process of online shopping. The consumer's previous experience with the firm's site can be evaluated positively, valuable or negatively, valueless. Making predictions based on benefits and value received, prior experiences are impact on consumer trust positively. 


\section{Word of Mouth (WOM)}

The relationship between perceived risk and perceived value are crucial for online shopping. Willingness to buy and recommend (word of mouth- WOM) is highly related within the context of perceived risk and value. According to Bone(1992:579) WOM stated as a group phenomenon: 'an exchange of comments thoughts, ideas among two or more individuals in which none of the individuals represents a marketing source'. WOW is an exchange process of the customers' like to shop, buy products, and recommend firstly to friends, relatives and then others (Samson, 2010; 459-461).

Social networking applications are user-generated and user-centered. Unlike traditional media, new media enables word of mouth (WOM) communication as very important for online shopping. Given the central role to third parties, it is important to explore users' perceptions of received informations' effectiveness. Especially, when a user confronted to make a purchasing decision for high risky(hedonic) products (Cheema and Kaikati, 2010: 553; Zhang and Daugherty, 2009;53-54).

This networking experience provides a user to be "self-knowledged" which highlights an individual cognitively regards him/herself as more knowlegable or better informed. Eventhough every user has a personal opinion, third person effect comprises the need for approval (Cengiz \& Yayla, 2007; Allsop et al.,2007). Hence, this trust based an interactive information sharing predicts to increase online shopping intention.

\section{Intention to online shopping}

The main interrelation of online shopping is not only between the seller and buyer, but rather between the buyer and mediated environment. It seems that online shoppers specifically like the freedom and control of completing a transaction without a physical social interaction. This confirms that e-user values the individual surfing through blogs to receive hedonic/functional utility, evaluate alternatives and personalized experiences. Blog marketing usually takes place through product recommendations. The power of recommendations on creating intention to buy may be recognized as a hidden marketing communication tool like a commercial that effect the viewers' opinion negatively (Lilijander et al, 2015: 611).

The vlog viewers react to revealed recommendations that are assumed to be sponsored by a company (Colliander and Erlandsson, 2015). However, previous researches have shown that the credibility of the information given has a positive effect on consumers' product attitude. Hence, both bloggers and firms need to understand how viewers react to profit seeking marketing communications versus experienced personal sharing. 


\section{Conceptual framework and hypotheses development}

As, well-known theories such as TRA, TAM explain that the consumers' behavioral intention is affected by his/her attitude toward the related behavior.This study identified the factors affecting online buying intention in the context of trust and word of mouth behaviour. Consumers search for product information and experiences from various reference groups and personal media such as vlog in order to get rid of uncertainty (Johnson and Kaye, 2009; Lee and Youn, 2009).The major aim for this study is to analyze that vloggers characteristics can affect customer's online purchase intention and sharing information behaviour differently.

As a result of the literature review, in this study, it can be proposed that trust would positively affect vblog users' attitudes and behavioral intentions to shop online.

Thus, the discussion leads to the following hypotheses;

$\mathrm{H}_{1}$ : Vlogger Characteristics have an effect on Vlogger Trust

$\mathrm{H}_{2}$ : Vlogger Characteristics have an effect on WOM

$\mathrm{H}_{3}$ : Vlogger WOM has an effect on Intention to online-shopping

$\mathrm{H}_{4}$ : Vlogger Trust has an effect on Intention to online-shopping

With these hypotheses in place, a conceptual model is illustrated in Figure 1.

Based on these hypotheses, the research model is structured to explain how vlogger characteristics affect intention to online shopping with the mediating effect of trust and WOM.

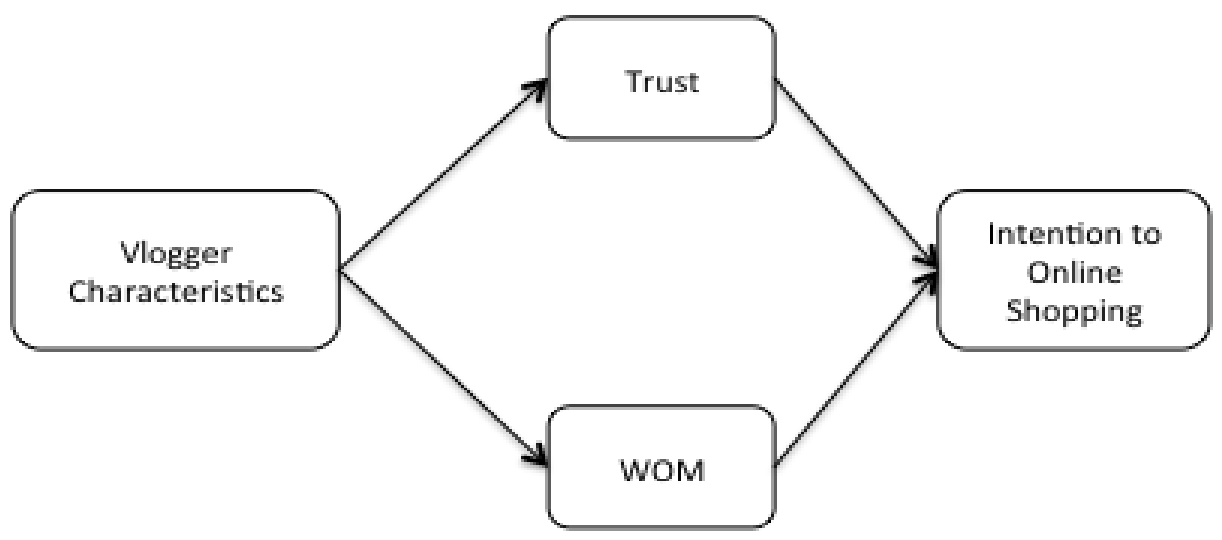

Figure 1. Conceptual model

\section{Methodology}

\section{Measures}

To conduct hypothesis testing, constructs were measured using multi items from the survey instrument. All items were measured using a five-point Likert scale ranging from $1=$ Strongly 
Agree to 5=Strongly Disagree. The questionnaire had two parts: demographic profile and construct items.

In this study previously developed and validated scales are used to measure the constructs. Vlogger Characteristics measures were derived from Blogger characteristics literature adopted from Doyle et al. (2012), with two sub-dimensions: Engagement Knowledge and Authoritative Knowledge. Three items that are used are developed by Wiedmann et al.(2010) to measure WOM. Vlogger Trust is measured by adopted three items from Hsu et al. (2013) and Lim et al. (2006). The scale to measure the Intention to Online Shopping, was adapted from (Mikalef et al. (2013), To et al. (2007) and Hsu \& Tsou (2011). The scales used to measure the four constructs are summarized in Table 1.

Table 1. Measurement items

\begin{tabular}{|c|c|c|c|}
\hline Construct & Item & Measurement & Reference \\
\hline \multirow{3}{*}{$\begin{array}{l}\text { Vlogger } \\
\text { Trust }\end{array}$} & TRUST1 & I believe Vloggers' recommendations to be true & \multirow{3}{*}{ Hsu et al., 2013; } \\
\hline & TRUST2 & I trust information on Vlogs to be true & \\
\hline & TRUST3 & Vloggers are trustworthy & \\
\hline \multirow{5}{*}{ WOM } & WOM1 & I like to share information about Vlogs. & \multirow{5}{*}{ Wiedman et al.,2010 } \\
\hline & WOM2 & I like to seek advice or information about Vlogs. & \\
\hline & WOM3 & $\begin{array}{l}\text { I like to encourage my close friends or family for } \\
\text { watching Vlogs. }\end{array}$ & \\
\hline & WOM4 & $\begin{array}{l}\text { I share my comment about Vlog if my experience is } \\
\text { negative. }\end{array}$ & \\
\hline & WOM5 & $\begin{array}{l}\text { I share my comment about Vlog if my experience is } \\
\text { positive. }\end{array}$ & \\
\hline \multirow{3}{*}{$\begin{array}{l}\text { Intention to } \\
\text { shop Online }\end{array}$} & ITOS1 & I buy products I see on blogs through e-shops. & \multirow{3}{*}{$\begin{array}{l}\text { Mikalef et al., 2013; To } \\
\text { et al., 2007; Hsu \& } \\
\text { Tsou } 2011\end{array}$} \\
\hline & ITOS2 & Blogs are a good way to shop online. & \\
\hline & ITOS3 & I will strongly recommend others to shop online & \\
\hline \multicolumn{4}{|c|}{ Vlogger Characteristics } \\
\hline \multirow{8}{*}{$\begin{array}{l}\text { Authoritative } \\
\text { Knowledge }\end{array}$} & AUKN1 & Has a business on the topic area & \multirow{15}{*}{ Doyle et al., 2012} \\
\hline & AUKN2 & Has one or more university degrees & \\
\hline & AUKN3 & Has specialized education in the topic area & \\
\hline & AUKN4 & Has won awards related to the area & \\
\hline & AUKN5 & $\begin{array}{l}\text { Has written a book or academic journals about the } \\
\text { topic }\end{array}$ & \\
\hline & AUKN6 & Teaches courses on the topic & \\
\hline & AUKN7 & Works in the industry & \\
\hline & AUKN8 & Writes about the topic in mainstream media & \\
\hline \multirow{7}{*}{$\begin{array}{l}\text { Engagement } \\
\text { Knowledge }\end{array}$} & EGKN1 & Has wide-ranging experience & \\
\hline & EGKN2 & Has extensive experience in the area & \\
\hline & EGKN3 & Has resources that that others do not & \\
\hline & EGKN4 & Is heavily involved in the area & \\
\hline & EGKN5 & Is passionate about the topic & \\
\hline & EGKN6 & Is very critical in discussing the topic & \\
\hline & EGKN7 & Is very engaged in the topic field & \\
\hline
\end{tabular}




\begin{tabular}{l|l|l|l}
\hline & EGKN8 & Is interested in topic-area improvements & \\
\cline { 2 - 3 } & EGKN9 & Spends a lot of time studying the topic & \\
\cline { 2 - 3 } & EGKN10 & Knows about unusual aspects of the topic \\
\cline { 2 - 3 } & EGKN11 & Uses correct terminology & \\
\hline
\end{tabular}

\section{Sampling and data collection}

Data was collected in the Fall, 2016 from 400 undergraduate and graduate students at Marmara University and Istanbul Commerce University with convenience sampling. Based on previous related researchs, young adults use technological mediums such as blogs/vlogs heavily (Huang et al.,2008; Lenhart and Fox, 2006). Therefore, respondents were chosen from the age between 18-35. Respondents were included in the study only if they reported following any Vlogger. Respondents with missing data were dropped and 357 questionnaires were used for testing the model.

Table 2. Demographic characteristics of survey respondents $(\mathrm{N}=385)$

\begin{tabular}{llll}
\hline Demographic profile & & Frequency & Percent (\%) \\
\hline Gender & Female & 212 & 55.1 \\
& Male & 173 & 44.9 \\
\hline Marital Status & Married & 64 & 17.4 \\
& Single & 318 & 82.6 \\
\hline Education & High school or below & 69 & 18.7 \\
& University & 287 & 74.5 \\
& Graduate & 26 & 6.8 \\
\hline Income & Up to 1000 TL & 185 & 48.8 \\
& $1001-2000 \mathrm{TL}$ & 82 & 21.3 \\
& 2001-3000 TL & 54 & 14.0 \\
& $3001-4000 \mathrm{TL}$ & 44 & 11.4 \\
& More than 4001 TL & 17 & 4.4 \\
\hline
\end{tabular}

The sample comprised of 212 Females and 173 Males. Ages of the sample ranged between 18 to 35 with 24,58 standard deviation 3.24 .

To enhance the personal relevance of the study, research participants were directed to respond to questions on their beliefs about specific/ topic-area vlogs that they watch most.

\section{Analysis and findings}

The main purpose of the study is to examine how the vlog instrument manages the intent to purchase online and which factors are effective in this regard. To determine whether vblog user's trust toward the vlogger to be significant in affecting the useful perception of vlogger's recommendation and how these perceptions influence attitudes and behavioral intentions in an online shopping context.

To identify and test the underlying structure of the scales exploratory factor analyses (EFA) were employed to each measurement as the initial step. The EFA results were further validated with confirmatory factor analyses (CFA). Kaiser-Meyer-Olkin measure of sampling 
adequacy and Bartlett test of sphericity tests were performed to test the appropriateness of data for conducting factor analyses (Sharma, 1996). Results of the tests were satisfactory. Principal Component Factoring and Varimax rotation were employed to the data set. Factors

with eigenvalues over one were retained and items with factor loadings below 0.50 and items with high cross loadings were excluded (Hair et. al., 2006; Netemeyer et al.,2003).

As can be seen from Table 3., Vlogger Characteristics emerged into two factors with $65.54 \%$ explained variance. The factors were named as "Engagement Knowledge" and "Authoritative Knowledge". Reliabilities for factors were 0.797 and 0.839 respectively. EFA results of Vlogger Trust, WOM and Intention to shop online showed that all three scales were uni-dimentional as expected. Reliabilities for each construct were $0.840,0.888$ and 0.889 respectively. To test the internal consistency of factors, Cronbach's coefficient alpha reliabilities were estimated. As it is shown the reliability measures of constructs ranged from 0.797 to 0.939 , which shows satisfactory levels of internal consistency (See Table 3).

Table 3. Exploratory and confirmatory factor analyses of components

\begin{tabular}{|c|c|c|c|}
\hline Constructs & $\begin{array}{l}\text { EFA } \\
\text { loadings }\end{array}$ & $\begin{array}{l}\text { CFA } \\
\text { loadings }\end{array}$ & $T$ \\
\hline \multicolumn{4}{|c|}{ Vlogger Characteristics $\left(\mathrm{KMO}=0.825, \chi^{2}\right.$ Bartlett test $\left.(28)=1144.498, \mathrm{p}=0.00\right)$} \\
\hline \multicolumn{4}{|l|}{ Engagement Knowledge } \\
\hline EGKN7 & 0.801 & 0.799 & $A$ \\
\hline EGKN5 & 0.791 & 0.675 & $12.189 * *$ \\
\hline EGKN8 & 0.774 & 0.686 & $12.375 * *$ \\
\hline EGKN9 & 0.718 & 0.760 & $12.296 * *$ \\
\hline EGKN10 & 0.708 & 0.805 & $12.797 * *$ \\
\hline \multicolumn{4}{|l|}{ Authoritative Knowledge } \\
\hline AUKN6 & 0.877 & 0.845 & $A$ \\
\hline AUKN5 & 0.835 & 0.760 & $12.946 * *$ \\
\hline AUKN3 & 0.744 & 0.674 & $11.894 * *$ \\
\hline \multicolumn{4}{|c|}{ Trust $\left(\mathrm{KMO}=0.694, \chi^{2}\right.$ Bartlett test $\left.(3)=471.405, \mathrm{p}=0.00\right)$} \\
\hline TRUST2 & 0.905 & 0.883 & $14.252^{* * *}$ \\
\hline TRUST1 & 0.894 & 0.849 & $13.991 * *$ \\
\hline TRUST3 & 0.812 & 0.682 & $A$ \\
\hline \multicolumn{4}{|c|}{ WOM $\left(\mathrm{KMO}=0.824, \chi^{2}\right.$ Bartlett test $\left.(10)=1024.496, \mathrm{p}=0.00\right)$} \\
\hline WOM2 & 0.846 & 0.846 & $17.838 * *$ \\
\hline WOM1 & 0.845 & 0.817 & $A$ \\
\hline WOM3 & 0.834 & 0.821 & $17.215^{* * *}$ \\
\hline WOM4 & 0.826 & 0.683 & $13.688 * *$ \\
\hline WOM5 & 0.804 & 0.663 & $13.098 \square$ \\
\hline \multicolumn{4}{|c|}{ Intention to Online Shopping $\left(\mathrm{KMO}=0.907, \chi^{2}\right.$ Bartlett test $\left.(36)=2722.318, \mathrm{p}=0.00\right)$} \\
\hline ITOS1 & 0.919 & 0.822 & $A$ \\
\hline
\end{tabular}




\begin{tabular}{l}
\hline ITOS2 \\
\hline ITOS3 \\
$\chi^{2}(140, N=357)=301.957, p=.00 ;$ GFI=0.918, NFI=0.923, CFI=0.957, TLI=0.947, RMSEA $=0.057$ \\
$\alpha=$ Cronbach's Reliability; VE= Variance Explained; CR= Construct Reliability; \\
AVE=Average variance extracted
\end{tabular}

Then confirmatory factor analyses (CFA) were conducted using IBM SPSS AMOS 23.0 program to validate the factors proposed by EFAs.

Chi-square test statistics are usually quite sensitive to sample size (Hair et. al. 2006; Hoyle 1995), therefore in this study; Goodness of Fit Index (GFI), Comparative Fit Index (CFI), Normed Fit Index (NFI), Tucker Lewis Index (TLI) and Root Mean Square Error Approximation (RMSEA) were considered. Results of EFA and CFA for each construct are explained below.

The procedures to check for convergent validity and discriminant validity were practiced (Anderson and Gerbing, 1988; Fornell and Larcker, 1981). Construct reliabilities of 0.715, $0.849,0.878,0.890$, and 0.804, indicated high internal consistency of the dimensions (Hair et al. 2006; Netemeyer et al. 2003). Average variance extracted (AVE) values, which reflect the overall amount of variance accounted for by the latent constructs, were all above 0.50 threshold; AVEs ranged between 0.576 to 0.730 (Fornell and Larcker 1981). Items under each construct, factor loadings, Cronbach's alpha and construct reliabilities are given in Table 3.

The various fit indices for the CFA suggested good fit to the data $\left(\chi^{2}(140, N=357)=301.957\right.$, $\mathrm{p}=0.00$, Goodness of Fit Index $(\mathrm{GFI})=0.918$, Comparative Fit Index $(\mathrm{CFI})=0.957$, Normed Fit Index $(\mathrm{NFI})=0.923$, Tucker-Lewis Index $(\mathrm{TLI})=0.947$, Root Mean Square Error Approximation $($ RMSEA $)=0.057)$. There is no standard for acceptable GFI, but rule of thumb is GFI greater than 0.90 (Lattin et al., 2003) and RMSEA values of 0.08 and less have been advocated as indicative of acceptable fit. But some authors propose a value of 0.06 or less as desirable ( $\mathrm{Hu}$ and Bentler 1999; Lattin et al., 2003). Consequently goodness of fit indexes supported the proposed model as fit.

\section{Structural model}

Since the objective of this study was to identify dimensions that increased Intention to shop online, a structural model was tested. The result of the path analysis showed a good fit of the model $\left(\chi^{2}\right.$ $(143)=381.595, \mathrm{p}=0.00 ; \mathrm{GFI}=0.903, \mathrm{CFI}=0.936, \mathrm{NFI}=0.903$, TLI=0.957, RMSEA=0.068).

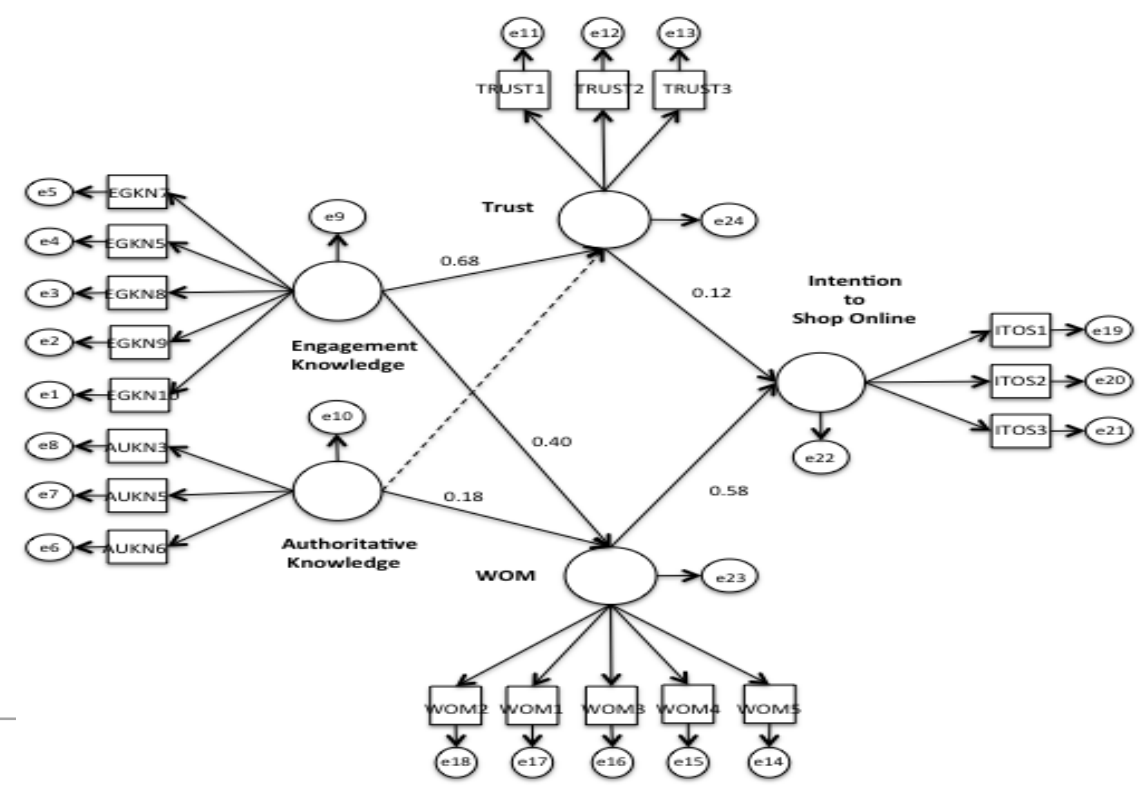




\section{Figure 2.}

Graphical representation of path model

As a result of the path analysis it was found that the Intention to Shop Online was explained by Trust and WOM. Engagement Knowledge and Authoritative Knowledge explained WOM. Trust was explained only by Engagement Knowledge.

Table 4. Results of path models

\begin{tabular}{|c|c|c|c|c|c|}
\hline \multirow{2}{*}{$\begin{array}{l}\text { Paths } \\
\text { Engagement Knowledge } \rightarrow \text { WOM }\end{array}$} & \multicolumn{3}{|c|}{$\begin{array}{l}\text { Standardized } \\
\text { coefficient }\end{array}$} & \multicolumn{2}{|l|}{ t value } \\
\hline & \multicolumn{2}{|c|}{0.499} & \multicolumn{3}{|c|}{$6.681 * * *$} \\
\hline Engagement Knowledge $\rightarrow$ Trust & \multicolumn{2}{|c|}{0.636} & \multicolumn{3}{|c|}{$9.539 * * *$} \\
\hline Authoritative Knowledge $\rightarrow$ WOM & \multicolumn{2}{|c|}{0.145} & \multicolumn{3}{|c|}{$3.136 \square$} \\
\hline Authoritative Knowledge $\rightarrow$ Trust & \multicolumn{2}{|l|}{ NS } & \multicolumn{3}{|r|}{ NS } \\
\hline Trust $\rightarrow$ Intention to shop online & \multicolumn{2}{|r|}{0.184} & \multicolumn{3}{|c|}{$2.369 \square \square \square$} \\
\hline WOM $\rightarrow$ Intention to shop online & \multicolumn{2}{|r|}{0.639} & \multicolumn{3}{|c|}{$9.643 \square$} \\
\hline $\begin{array}{l}\left(\chi^{2} \quad(\mathbf{1 4 3})=381.595, \quad \mathbf{p}=\mathbf{0 . 0 0} ;\right. \\
\text { Note. } \square p<.05, \square \square p<.01, \square \square \square p<\end{array}$ & $\begin{array}{l}\text { GFI=0.903, } \\
.001\end{array}$ & $\mathrm{CFI}=0.936$ & & $\mathrm{FI}=0.903$, & $\mathbf{T L} \mathbf{I}=\mathbf{0 . 9 5 7}$ \\
\hline
\end{tabular}

Engagement Knowledge with WOM has a significant affect on WOM $(\beta=0.499, \mathrm{p}$ value $=$ $0.00)$. Engagement Knowledge with WOM has a strong affect on WOM $(\beta=0.636, p$ value $=$ $0.00)$. On the other hand, Authoritative Knowledge only affects WOM $(\beta=0.145, \mathrm{p}$ value $=$ $0.02)$. Trust $(\beta=0.184, p$ value $=0.18)$ and $\operatorname{WOM}(\beta=0.639, p$ value $=0.00)$ have an affect on Intention to shop online.

\section{Conclusions and future directions}

In todays social media world, blogs are still the most influential digital medium that consumers, either for trust, or for popularity and influencial ability, tend to integrate with, to learn, participate, share, apply and/or buy. Consumers today are at reach to information 
easily. Since they have more power to select through products and evaluate properness of effective communication, companies are forced to open higher spectacle opinion leaders to increase online shopping and viral communication behaviours.

Companies used to choose celebrity endorsed advertising methods, especially on conventional media. But today celebrity endorsement are unpersuasive to consumers. With the increased use of social media applications companies urged to attract authoriaties or typical consumers who have personally experienced their products to write relevant comments. Recommendation of a product from a third party perspectives mobilize advertising effectiveness and also clarify the blurry gap between brands and online shoppers.

From a practical perspective, blog-readers desire to spread information from engagementknowledged vlogger rather than authoritative-knowledged vlogger. Any information online that is individually experienced is worthy and more effective than authoritative or theoric information sharing. Since, the traditional word of mouth marketing has been revived through the online media as viral marketing, it is important to create intention for persuading receivers into spreading information to their social network and so forth. Viral marketing is an increasingly popular tactic for marketing communicative strategy that companies should prefer to launch viral campaigns on real, ordinary and credible people's experiences. The aim of viral strategy is to be centered on being natural and inspirational. If online users believe that the shared information is trustworthy they would play a part in sharing with their social environment. Besides conscious online users could percieve and interpret companies'viral communicative startegy differently. For instance, they may be challenged due to the lack of background knowledge or may see no connection between the purpose of the campaign and the message or either strongly feel that whole purpose is a tactic for direct selling. Due to avoidance of any further confusion and negative impact, the main purpose of online communicative strategy should be constructed on real feelings and experiences in order to promote the core nature of word of mouth communication and purchase intention of any product.

Whether companies like it or not, people chat online about a lot of things. From advertisement to opinions on blogs or forums, people do online discussions about the variety of products and services. Most of the online users have found that social set-ups have greater influence on others. Third person influences on individuals' behaviors aim to decide, create intention to buy or apply word of mouth communication. In social media any individual may present different role (giver or reciever of an information) depending on the topic. Nowadays online users are persuaded to finalize the buying process of a product with the encouragement of the companies and social media interactions. When people share information on social media, they can easily see how many people feel the same as themselves and thus they are more motivated to make purchases. In the past, this motivation had been interrupted by the necessity of passing another platform (such as whatsup or phone) for payment process. The brands which lead to uninterrupted and totally-online managed buying process would be counted as successful for increasing online selling by effective social media usage. 
Since the limitation of this study includes convenience sampling, limits the generalizibility, It can be suggested that the research can be applied to different demographic features such as age, gender and income level. Additionally, comparison between different product categories and culture can be considered in future studies.

\section{REFERENCES}

Alba, J.W \& Hutchinson, J. W. (1987) Dimensions of Consumer Expertise, The Journal of Consumer Research, Vol. 13, No. 4., 411-454.

Allsop, D.T., Bassett, B.R. \& Hoskins,J.A (2007) Word of mouth research: principles and applications. Journal of Advertising Research, Vol.47, No.4, 398-411.

Anderson, J. C. \& Gerbing, D. W. (1988). Structural equation Modeling in Practice:

A Review and Recommended Two-Step Approach. Psychological Bulletin 103(May): 411-423.

Bone, P.F.(1992).Determinants of word of mouth communications during product consumption, Advances in Consumer Research,Vol.19,579-583.

Cengiz, E and Yayla, H.E . (2007). The effect of marketing mix on positive word of mouth communication: Evidence from accounting offices in Turkey. Innovative Marketing, Vol.3, No.4, 73-86.

Cheema, A. \& Kaikati A.M. (2010) The Effect of Need for Uniqueness on Word of Mouth. Journal of Marketing Research, Vol. 47, No. 3, 553-563.

Chen, W. \& Hirschheim, R. (2004), A paradigmatic and methodological examination of

information systems research from 1991 to 2001, Information Systems Journal, Vol. 14,197-235.

Chiou, J. (2004). The antecedents of consumers' loyalty toward internet service providers. Information \& Management, Vol.41, No.6, 685-695.

Cho, J. (2006). The mechanism of trust and distrust forming and their relational outcomes. Journal of Retailing, Vol.82, No.1, 25-35.

Colliander, J. \& Erlandsson S. (2015).The blog and the bountiful: Exploring the effects of disguised product placement on blogs that are revealed by a third party, Journal of Marketing Communications, Vol.21, No.2, 110-124.

Davis, F.D. (1989), “Perceived usefulness, perceived ease of use, and user acceptance of information technology", MIS Quarterly, Vol. 13 No. 3, 319-339. 
Doyle, D. J., Heslop, A. L., Ramirez, A. \& Cray D. (2012). “Trust intentions in readers of blogs", Management Researeh Review, Vol.35, No.9, 837-856

Egea, J.M.O. \& Gonza'lez, M.V.R. (2011). Explaining physicians' acceptance of EHCR systems: an extension of TAM with trust and risk factors, Computers in Human Behavior, Vol. 27 No. 1, 319-332.

Fernando, A. (2007). Social media change the rules: Say farewell to top-down and hello to consumerled communication, Communication World, 24 (1), 9-10.

Fishbein, M. \& Ajzen, I.(1975). Belief, Attitude, Intention and Behavior: An

Introduction to Theory and Research, Addison-Wesley, Reading, MA.

Fornell, C. \& Larcker F. D.(1981). Evaluating Structural Equation Models with Unobservable Variables and Measurement Error. Journal of Marketing Research Vol:18, 39-50

Gefen, D., Karahanna, E. \& Straub, D.W. (2003). Trust and TAM in online shopping: an

integrated model, MIS Quarterly, Vol. 27, No. 1, 51-90.

Hair Jr. F. J., Black C. W., Babin J. B., Anderson E. R., \& Tatham L. R. (2006). Multivariate Data Analysis. Upper Saddle River, NJ: Prentice Hall Inc.

Heaney, J. (2007). Generation X and Y's internet banking usage in Australia. Journal of Financial Services Marketing, Vol. 11, No.3, 196-210.

Hsu, C.L. \& Lin,C.J.(2008), Acceptance of blog usage: the roles of technology acceptance,

social influence, and knowledge sharing motivation, Information \& Management, Vol. 45

No. 1, 65-74.

Hsu, C.L., Lin, C. J. \& Chiang H. (2013), “The effects of blogger recommendations on customers' online shopping intentions", Internet Research,Vol.23, No.1, 69-88

Hsu, H. \& Tsou, T. (2011). Understanding Customer Experiences in Online Blog Environments. International Journal of Information Management, Vol.31, 510-523.

Hsu, M.-H., Tien, S-W., Lin , H.-C., Chang, C.-M. (2015). Understanding the roles of cultural differences and socio-economic status in social media continuance intention, Information Technology \& People, Vol. 28, No.1, $224-241$.

Huang, L., Chou, Y. \& Lin, C. (2008), The influence of reading motives on the responses after reading blogs, CyberPsychology \& Behavior, Vol. 11, No. 3, 351-355.

Hu, L.T. and Bentler, P.M. (1999). Cutoff Criteria for Fit Indexes in Covariance Structure Analysis: Conventional Criteria Versus New Alternatives, Structural Equation Modeling,Vol. 6, No.1, 155.

Johnson, T.J. and Kaye, B.K. (2009). In blog we trust? Deciphering credibility of components of the internet among politically interested internet users, Computers in Behavior, Vol. 25 No. 1, 175182. 
Lattin,J.M., Carroll,J.D. \& Green P.E. (2003). Analyzing Multivariate Data, Duxbury applied series, Thomson Brooks/Cole.

Lee, M. \& Youn, S. (2009). Electronic word of mouth (eWOM): How eWOM platforms influence consumer product judgement. International Journal of Advertising, Vol. 28, No.3, 473-499.

Lenhart, A. \& Fox, S. (2006). Bloggers: A Portrait of the Internet's New Storytellers, Pew Internet \& American Life Project, Washington, DC.

Liljander, V., Gummerus, J., Söderlund, M. (2015). Young consumers' responses to suspected covert and overt blog marketing, Internet Research, Vol.25, No.4, 610-632.

Lim, K., Sia, C., Lee, M. \& Benbasat, I. (2006). Do I trust you online, and if so, will I buy?

An empirical study of two trust-building strategies, Journal of Management Information

Systems, Vol. 23, No. 2, 233-266.

Lu, H.-P. \& Hsiao, K.-L. (2007).Understanding intention to continuously share information on weblogs. Internet Research, Vol. 17, No: 4, $345-361$.

Mikalef, P., Giannakos, M., \& Pateli, A. (2013). Shopping and word-of-mouth intentions on social media. Journal of Theoretical and Applied Electronic Commerce Research, Vol.8, No.1,17-34.

Mooney, K. and Rollins, N. (2008), The Open Brand: When Push Comes to Pull in a Web-made World, New Riders, Thousand Oaks, CA.

Morton, L. P. (2002). Targeting Generation Y. Public Relations Quarterly, Vol. 47, No.2, 46-48.

Netemeyer, R., G. Bearden, W. O. \& Sharma, S. (2003). Scaling Procedures: Issues and Applications. Thousand Oaks, CA: Sage Publication.

Ponterotto, J. (2005). Qualitative research in counseling psychology: a primer on research

paradigms and philosophy of science, Journal of Counseling Psychology, Vol. 52, No. 2, 126-136.

Samson, A. (2010) Product usage and firm-generated word of mouth: some results from FMCG product trials. International Journal of Market Research, Vol.52, No. 4, 459 -482.

Scott, C.R. (2007), "Anonymity and self-disclosure on weblogs", Journal of Computer-Mediated Communication, Vol. 12 No. 4, pp. 1428-1451.

Sharma, S.(1996) Applied Multivariate Techniques, John Wiley \& Sons, Inc. 
Stelzner, M.A.(2011). 2011 Social Media Marketing Industry Report Retrived from: http://www.socialmediaexaminer.com/social-media-marketing-industry-report2011.:10.11.2016.

Suk, K., \& Mitchell, A. (2004). The effect of usage situation familiarity on memory, brand retrieval and consideration (Unpublished report/2004), Toronto, ON, Canada, University of Toronto.

Technorati Media. (2012). Technorati Media Report,Digital Report 2012. Retrieved from http://www.technorati.com; 10.11.2016.

To, P., Liao, C. \& Lin, T. (2007). Shopping motivations on internet: A study based on utilitarian and hedonic value. Technovation, Vol. 27, 774-787.

Tung, F.C., Chang, S.C. \& Chou, C.M. (2008), “An extension of trust and TAM model with IDT in the adoption of the electronic logistics information system in HIS in the medical

industry", International Journal of Medical Informatics, Vol. 77, No. 5, 324-335.

Venkatesh, V. \& Bala,H. (2008). Technology acceptance model 3 and a research agenda on interventions. Decision Sci.,Vol. 39, 273-315.

Wiedmann, K.P., Hennigs, N., Pankalla, L., Kassubek, M., Seegebarth, B. \& Reeh, M.O.(2010). Online distribution of pharmaceuticals: investigating relations of consumers' value perception, online shopping attitudes and behaviour in an e-pharmacy context. Journal of Consumer Behaviour, Vol.9, No.2, 175-199.

$\mathrm{Wu}$, C.M. (2011).How quality influence user's continuance of the recommendation blog, Key Engineering Materials,Vol. 474-476, 1132-1136.

Yueh H.P, Chen T.L, Chiu L.A \& Lin W.C. Exploring factors affecting learner's perception of learning information and communication technology: A HLM analysis of a national farmers' training program in Taiwan. Educational Technology and Society, Vol.16, 231-242.

Zhang, J. \& Daugherty, T. (2009). Third-Person Effect and Social Networking:

Implications for Online Marketing and Word-of-Mouth Communication, American Journal of Business, Vol. 24, No. 2, $53-64$. 
